\title{
The Savings of Ordinary Americans: The Philadelphia Saving Fund Society in the Mid- Nineteenth Century
}

\section{Citation}

Alter, George, Claudia Goldin, and Elyce Rotella. 1994. The savings of ordinary Americans: The Philadelphia saving fund society in the mid-nineteenth century. Journal of Economic History 54(4): 735-767.

\section{Published Version}

http://dx.doi.org/10.3386/w4126

\section{Permanent link}

http://nrs.harvard.edu/urn-3:HUL.InstRepos:2643655

\section{Terms of Use}

This article was downloaded from Harvard University's DASH repository, and is made available under the terms and conditions applicable to Other Posted Material, as set forth at http:// nrs.harvard.edu/urn-3:HUL.InstRepos:dash.current.terms-of-use\#LAA

\section{Share Your Story}

The Harvard community has made this article openly available.

Please share how this access benefits you. Submit a story.

\section{Accessibility}




\title{
THE JOURNAL OF ECONOMIC HISTORY
}

\section{The Savings of Ordinary Americans: The Philadelphia Saving Fund Society in the Mid-Nineteenth Century}

\author{
George Alter, Claudia Goldin, and Elyce Rotella
}

We explore the savings behavior of ordinary Americans through their accounts at the Philadelphia Saving Fund Society, the oldest mutual savings bank in the United States. Our sample contains all 2,374 accounts opened in 1850. Savings accounts were generally brief affairs, but median balances mounted to about three-quarters of annual income in three years. Deposits and withdrawals were infrequent, but substantial. Only female servants, as a group, used their accounts for life-cycle savings, eventually amassing large nest eggs. Men often used them to hold funds before acquiring physical property. We estimate saving rates between 10 and 15 percent on active accounts.

To promote economy and the practice of saving amongst the poor and laboring classes of the community-to assist them in the accumulation of property that they may possess the means of support during old age or sicknessand to render them in a great degree independent of the bounty of others... Of the charitable Institutions that have had for their object the amelioration of the human condition, none perhaps deserve higher commendation

The Journal of Economic History, Vol. 54, No. 4 (Dec. 1994). (C) The Economic History Association. All rights reserved. ISSN 0022-0507.

George Alter is Associate Professor of History at Indiana University, Bloomington, IN 47405. Claudia Goldin is Professor of Economics at Harvard University, Cambridge, MA 02138, and Director of the Development of the American Economy Program at the National Bureau of Economic Research. Elyce Rotella is Associate Professor of Economics at Indiana University, Bloomington, IN 47405.

We gratefully acknowledge funding for the collection of the PSFS account data provided by the University of Pennsylvania through PARSS and the Work-Study Program and by Indiana University through a Grant-in-Aid of Research. Shawn Weldon and V. Chapman-Smith at PSFS facilitated data collection on site. Several undergraduate research assistants at the University of Pennsylvania were instrumental in the data collection. Lisa Schweitzer began the project and skillfully devised the protocol that subsequent assistants used in the linkage process. Thu Tran, Emily Becher, and Alex Gould followed her excellent example. Alex later collected the larger sample of PSFS accounts. We thank them all for their diligence. We are also grateful to Lance Davis who commented on an earlier version presented at the Economic History Association in September 1991. Lee Craig, William English, Alan Olmstead, Elmus Wicker, and seminar participants at the University of Arizona, the Federal Reserve Bank of Cleveland, Indiana University, Research Triangle, UCLA, and the University of Iowa all offered valued suggestions for improvement. 
than those which, under the title of Provident Societies or Savings Banks, have lately been established throughout the kingdom of Great Britain.

- "Address of the Philadelphia Saving Fund Society to the Public," December 13, 1816 ${ }^{1}$

$\mathbf{T}$ The quest to understand how nations grow and how their residents achieve economic security has led economists and historians to explore the subject of savings. Aggregate savings are key to the process of economic growth because they are the basis of capital formation. Growth of the U.S. economy in the nineteenth century was stimulated by a substantial increase in the aggregate saving rate. ${ }^{2}$ This higher saving rate resulted from decisions made at the microeconomic level by individuals who saved for their own purposes-to tide themselves over rough times, to accumulate for major purchases, to prepare for old age, and to make bequests. Thus the macroeconomics and the microeconomics of saving are inextricably linked.

In this article we are more concerned with the microeconomics of individual saving behavior as revealed by the accounts of ordinary Americans who saved at the Philadelphia Saving Fund Society (PSFS) in the mid-nineteenth century. PSFS, the oldest mutual savings bank in America, was established, as stated in the epigram, to encourage thrift among the working poor. We believe that savings banks, by making it easier and safer for individuals to save, encouraged the increase of savings that generated growth at the macrolevel.

Potential savers of ordinary means in the mid-nineteenth century had limited opportunities to accumulate savings that were secure, liquid, and yielded attractive returns. The mattress and cookie jar were always available to those who wanted to squirrel away funds, but these could be insecure and did not yield a return. Physical assets, such as land and buildings, could be purchased by those with sufficient funds, but they were relatively illiquid. Consumer durables and semidurables, including clothing, jewelry, and furniture, were also illiquid means of holding assets, though they could be converted to cash at pawnshops. ${ }^{3}$ Savers

\footnotetext{
${ }^{1}$ Willcox, History, pp. 25-26.

${ }^{2}$ A statistic related to the saving rate, the ratio of gross private domestic capital formation to gross national product, increased greatly over the nineteenth century-from 12 percent in 1840 to 20 percent in 1900-before declining during the twentieth century (Davis and Gallman, "Capital Formation"'). See, however, Ransom and Sutch, "Domestic Saving," for somewhat revised saving rate data that diminish the magnitude of the saving rate increase across the nineteenth century. One may question why the domestic saving rate determines capital formation when a nation faces an interest rate in the world capital market. Although borrowing from abroad funded particular projects in the nineteenth century (for example, railroads), most domestic capital formation was funded by domestic savings. In large measure this is because most domestic capital formation was for relatively small projects, such as the building of homes, the clearing of land, and the accumulation of capital by firms.

3 Johnson, Saving, pp. 177-83.
} 
of ample means might hold the bonds of railroads or states or they might invest money in a commercial bank. But for the small savers, who were the great majority of Americans, there were few options. A fairly safe and convenient method available to those who lived in or around many of the nation's cities was to deposit their money in a savings bank. One of the largest was the Philadelphia Saving Fund Society (PSFS), chartered in 1816 and existing, in some form, to this day.

By using data from PSFS savings accounts, we observe time paths of savings accumulated by individuals at one particular financial institution. ${ }^{4}$ From these we draw inferences about motives for saving. Individuals and households save for a number of reasons. Much, but not all, saving is motivated by a desire to smooth consumption, that is, to have a pattern of consumption over time that is less variable than income. Sources of variability in income may be fairly predictable, as when there is planned retirement or seasonal unemployment. But income also varies for reasons that are difficult to predict, like cyclical layoff, sickness, and death. Saving motivated by a desire to smooth consumption over short-term variations in income, especially unplanned variations, is called precautionary saving. Saving for old age is called life-cycle saving. Another reason people save is to accumulate funds to make large purchases (for example, consumer durables or real estate) or large payments (for example, taxes, or balloon payments on mortgages). This is called target savings and is more common when credit markets are poorly developed. ${ }^{5}$

Our interest in discerning motives for saving comes from both the macroeconomic and microeconomic considerations with which we began. At the macroeconomic level, aggregate savings will be higher when they are motivated by life-cycle considerations, that is, retirement and bequests. On a microeconomic level, revelation of the motives for saving gives us insight into the ways Americans coped with economic insecurity before the development of the public and private network of safety nets in the forms of Social Security, Medicare, unemployment insurance, pensions, and health and life insurance. Markets were incomplete in the nineteenth century, and savings, physical assets, and dependence on family and friends took their place.

Our data set consists of all accounts at PSFS opened in 1850, and among adult savers they can be grouped as males (42 percent), female

\footnotetext{
${ }^{4}$ We do not know the income of account holders, although we can make inferences based on occupation. We also do not know if account holders accumulated wealth in other assets, though for some we have information on the value of real estate holdings.

${ }^{5}$ Although saving motives are often characterized as being ex post precautionary, target, or life cycle, saving is really the solution to a complex dynamic, stochastic optimization problem. The problem is implicitly solved by consumer units and yields a time path of saving, as well as consumption and asset accumulation. It is this time path of saving that we, following others, characterize under the three types mentioned. See Deaton, "Saving"; and King, "Economics," for a fine summary of the theory of saving.
} 
servants ( 23 percent), and female nonservants ( 35 percent). Our clearest results are for adult males, for whom we find substantial evidence of target-motivated saving, and female servants, many of whom appear to have been life-cycle savers in terms of their PSFS accounts. ${ }^{6}$ The group of female nonservants is so heterogeneous that we can draw few conclusions about their motives on the basis of their account histories.

In general, the median account began with $\$ 50$, or about 20 percent of a male laborer's annual income in 1850 . Subsequent deposits were about half that amount, although they occurred only about once a year; withdrawals (excluding the last) were somewhat larger than deposits, but occurred less frequently. Most importantly, withdrawals and deposits were rarely in small amounts. Accounts lasting from two to five years contained about 50 percent of a male laborer's gross annual income. Men's accounts were considerably briefer than women's, particularly those of female servants.

Half the accounts opened by adult males in 1850 lasted fewer than two years, and among accounts surviving to year two, more than half did not make it to five years. The majority of the accounts opened in 1850, then, were brief and did not survive to the Civil War period, which witnessed account closings on a large scale. Median balances in year four were between $\$ 200$ and $\$ 225$, or about eight-tenths of gross annual income for working-class men. Deposits were infrequent but large, and withdrawals were even less frequent and somewhat larger. Final withdrawals were substantial in size and could have been payments for physical assets, about which we have some independent evidence.

The accounts of servants had the longest duration. Slow, methodical saving left these women with large nest eggs in their advanced years. Whereas men commonly shifted their assets from the bank to physical forms, female servants, with fewer options of this nature, used the bank as their primary form of life-cycle saving.

Given their probable incomes, those who saved at PSFS had high rates of saving, although their use of the institution depended on their personal circumstances. Annual net saving among the adult male account holders was probably between 10 and 15 percent of their gross annual income during the active years of the account.

\section{NINETEENTH-CENTURY SAVINGS BANKS}

The Philadelphia Saving Fund Society commenced operation on December 2, 1816, thereby becoming the first savings bank in the United States. Its first account holder was a black male servant in the household of the founder, Condy Raguet, a merchant, diplomat, and

\footnotetext{
${ }^{6}$ We do not mean to imply that the adult males were not life-cycle savers, merely that they did not use their PSFS savings accounts to accomplish that goal. Rather, they often used their accounts to hold funds they would later use to purchase physical property.
} 
free-trade advocate who was influenced by literature on English savings banks. It was Raguet who suggested "that as the name of 'Bank' had become so unpopular with the Legislature, it would be expedient to call the institution by some other name in order to secure a Charter." the time the Saving Fund Society had received a charter from the state legislature in February 1819, there were savings banks in Boston, Baltimore, and a number of other cities. By 1820 , there were ten U.S. savings banks serving 8,635 depositors, 665 of whom had accounts at PSFS. $^{8}$

Those who founded and managed savings banks put forward a rationale of benevolence. PSFS, in its first public statement, defined savings banks as charitable institutions "to promote economy and the practice of saving amongst the poor and laboring classes of the community."9 They saw their institution as an appropriate place for saving motivated by precautionary, target, and life-cycle objectives. A pamphlet, laced with homilies from Franklin, publicized the bank's founding and trumpeted the virtues of "gradual accumulation and ultimate provision for the casualties of life and the wants of age." In a series of examples of accumulation based on regular deposits, the pamphlet shows how an apprentice could save enough to set up his own business and a family could provide dowries for children. ${ }^{10}$

The men who joined Raguet as officers of the Society were among the most prominent social and business leaders of Philadelphia. They promised to use their expertise to "afford a secure and profitable mode of investment for small sums (returnable at the will of the depositor on a short notice) to mechanics, tradesmen, laborers, servants and others, who have no friends competent or sufficiently interested in their welfare, to advise and assist them, in the care and employment of their earnings." "The legislature took seriously the claim that the Society was to serve the humbler members of the population and enacted a limit on aggregate deposits (eventually dropped in 1851), hoping to discourage acceptance of deposits from the wealthy. The limit on individual deposits imposed by PSFS from 1828 to 1869 was $\$ 200$ annually. ${ }^{12}$

Other scholars have considered the question of whether savings banks were in fact charitable institutions that served the poor and

${ }^{7}$ Willcox, History, p. 18.

${ }^{8}$ Payne and Davis, Savings Bank, p. 18; and Willcox, History, table following p. 166.

9 Willcox, History, p. 25.

${ }^{10}$ Ibid., pp. 35, 38-41.

11 Ibid., p. 26.

12 Ibid., p. 45, table following p. 166. Although it is not clear from the written record whether the limit of $\$ 200$ was placed on gross or net deposits, the accounts suggest that it was net. When the bank was founded there was no limit, but a limit of $\$ 500$ was imposed in 1819 in conjunction with the bank's receiving a charter from the state. This ceiling was reduced to $\$ 200$ in 1828 and remained in effect until inflation during the Civil War so eroded the dollar that the limit became binding on too many customers. It was raised to $\$ 500$ from 1870 to 1876 and then lowered to $\$ 300$ from 1876 to 1897 . 
working class. Albert Fishlow, in a study of British savings banks, finds that by far the largest group of depositors were servants. ${ }^{13}$ Small tradesmen, artisans, and otherwise unidentified women and children were also well represented among account holders, but few members of the industrial working class had accounts. Wealthy individuals, attracted by the high government-subsidized interest rate in British savings banks, held over half the aggregate account balances. In a detailed examination of the Savings Bank of Baltimore, Peter Payne and Lance Davis have argued that the Baltimore bank remained true to its stated philanthropic principles through the first half century of operation despite the lack of state oversight. ${ }^{14}$ Strict limits were placed on weekly deposits and periodically the bank examined its rolls and returned the deposits of those with large balances and employed in occupations untypical of "the thrifty poor." 15 Alan Olmstead, who studied 12 New York savings banks, expressed more skepticism regarding the stated philanthropic motives of savings bank trustees. ${ }^{16}$ He speculates that some who served as trustees did so to gain favored access to credit for real estate purchases and other ventures. ${ }^{17}$ In his examination of depositors, Olmstead found that despite the preponderance of servants and workers among account holders, many were members of the middle and upper classes who held substantial balances. ${ }^{18}$

Although our purpose is not to examine the motives of savings bank trustees, it appears that the Philadelphia Saving Fund Society maintained its philanthropic character. Among adult males who opened accounts in 1850 , nearly 50 percent had a trade, owned a store, or were professionals or skilled craftsmen. Because we have no information on income, occupation provides our only evidence regarding whether the bank fulfilled its objective of encouraging thrift among the lower-income groups in society. Even though a minority of male account holders were from the very lowest rungs of the occupational ladder, the proportion among women, as indicated by those who were servants, was considerably higher. ${ }^{19}$ The Society was among the most conservative of savings banks throughout at least its first century of operation. Its conservatism is revealed in the practice of holding a large contingent fund to guard the safety of its accounts. ${ }^{20}$

\footnotetext{
13 Fishlow, "Trustee Savings Banks."

${ }^{14}$ Payne and Davis, Savings Bank.

${ }^{15}$ Ibid., pp. 32-36.

16 Olmstead, New York City Mutual Savings Banks.

${ }^{17}$ Ibid., pp. 14-19.

18 Ibid., pp. 50-55.

${ }^{19}$ We do know that a few of the wealthier citizens of Philadelphia had accounts at PSFS. Among our account holders, for example, is a five-year-old named Wharton Sinkler, who was to become one of the city's richest men; there were also several Biddles, likely relatives of the bank's president in 1850, Clement Biddle.

${ }^{20}$ PSFS held a contingent fund that was considered large for its liabilities and therefore, some have claimed, it paid a lower rate of return than other banks. In 1851 the contingent fund at PSFS
} 
THE PHILADELPHIA SAVING BANK AT MIDCENTURY

By 1850 PSFS had 10,229 account holders and total deposits in excess of $\$ 1.7$ million. At this size it was considerably larger than the average U.S. savings bank at the time, which had 2,327 account holders and about $\$ 400,000$ in deposits. The average PSFS balance was $\$ 172$, exactly equal to the national mean. ${ }^{21}$

Although we do not know precisely, it is clear that a substantial fraction of all working-class Philadelphians had accounts at PSFS in 1850. We estimate that at least 4,521 of the existing PSFS accounts in 1850 were held by adult residents of the central portion of Philadelphia, of whom there were about 66,400 . Therefore, about 8 percent of all adult residents of the center city had a PSFS account in 1850 . The percentage of households with such accounts would have been substantially larger, perhaps double; and an even larger percentage would have had a PSFS account at some point in their lives. 22

The Society reached the 1850 s in good financial shape, having weathered the difficulties of the early 1840 s when all but nine commercial and savings banks in Philadelphia failed. By this time PSFS's investment portfolio was heavily dominated by mortgages of which the managers could say proudly that "not one cent of the principal has been lost by the Society." ${ }^{, 23}$ In the early 1850 s the bank was bumping against the statutory ceiling on aggregate deposits, which was removed in 1851 , allowing more rapid growth thereafter. The mid-1850s was an unsettled period in U.S. financial history, with financial panics in 1854 and 1857. The bank experienced a large deposit outflow and a decline in the number of accounts at the end of this period. This instability, however, was minor compared with the difficulties attending the early Civil War period when the number of accounts fell by 40 percent and total deposits were nearly halved. The bank met these extraordinary demands for

was 12.4 percent of all deposits (Willcox, History, table on unnumbered page following p. 166). Willcox notes that New York State law at that time required a contingent fund of 10 percent (p. 184). What information we have on interest rates paid by other Philadelphia savings banks does indeed suggest that the rate paid by PSFS was lower than that paid by some-but not all-others. Olmstead reports that the Bank for Savings in New York City was a prudent and conservative bank and often paid a lower rate than other mutual savings banks (New York City Mutual Savings Banks, table 3, p. 36).

${ }^{21}$ Philadelphia Saving Fund Society [hereafter, PSFS], Annual Report, 1850; and Payne and Davis, Savings Bank, p. 18.

22 The PSFS Annual Report, 1850 reports that 10,638 accounts existed at the end of that year. Based on age information in the linked accounts, we estimate that 15 percent of these accounts were held by (or in the names of) children. Therefore, 9,042 of the accounts existing in 1850 were held by adults. Based on addresses examined for the linkage process, we know that at least half $(5,421)$ of these account holders lived in the 17 central subwards of the city and the four closest wards to the north and the south. The adult population of the city is estimated by applying county-level age breakdowns to the city population, which yields an estimated adult population of 66,422 (U.S. Bureau of the Census, Seventh Census, pp. 154-57, 179).

${ }^{23}$ Willcox, History, p. 181. 
deposits by using its very large contingent fund and by selling securities from its portfolio. ${ }^{24}$ The experience confirmed the managers in their belief that a large contingent fund was efficacious, even though it meant paying lower interest rates than were offered by other savings banks in the city.

By 1850 , PSFS had grown considerably, was professionally managed, and occupied its own impressive building, but it still professed its original ideals. In his 1850 Annual Report, bank President Clement Biddle argued that evidence on deposits and withdrawals showed that "the benefits of the institution have been legitimately conferred on the large classes of humble and helpless, but thrifty and prudent, persons for whose protection, and consequent improvement, the Philadelphia Saving Fund Society was established." In that year, 38 percent of all male account holders were "mechanics, artisans, or handycraftsmen," and another 13 percent were "porters or labourers"; 43 percent of female account holders were "domestic servants, nurses, or housekeepers." 25 PSFS was quite similar to other savings banks in the clientele it served, particularly in its high representation of female servants.

\section{THE PHILADELPHIA SAVING FUND SOCIETY DATA}

The archives of PSFS contain two types of records with information on the Society's individual account holders. ${ }^{26}$ To open an account, a prospective depositor had to sign a "signature record" and furnish street address and occupation, in addition to depositing at least $\$ 1.00 .^{27}$ The bank then assigned an account number and recorded subsequent deposits, withdrawals, and account balances in enormous ledger books, as well as in the passbook issued to each account holder. There are, thus, two types of records in the archives: the "signature books" and the "account ledgers," connected to each other by account number as well as by the name of the account holder. We have collected information on all accounts that were begun in 1850 . Our choice of 1850 enables us to link account holders to the Philadelphia federal census manuscripts of that year. ${ }^{28}$

Our data come from two samples of PSFS accounts, one nested in the other. The "1850 Sample" is the complete population of all accounts opened during that year. The signature books provide name (from which

\footnotetext{
${ }^{24}$ Ibid., pp. $179-89$.

${ }^{25}$ PSFS, Annual Report, 1850.

${ }^{26}$ The Archives of PSFS were closed after the merger and reorganization of the bank in 1992. We were fortunate to have been able to use the signature and account books when the archives were in existence. We believe that these records are a unique set of documents. The records have recently been acquired by the Hagley Museum and Library, accession no. 2060.

${ }^{27}$ The bank imposed a minimum deposit of $\$ 1.00$ but did not pay interest on less than $\$ 5.00$.

${ }^{28}$ We chose not to use 1860 because those accounts would have been immediately affected by the financial turmoil attending the Civil War. The 1840 census manuscripts do not have the detail we needed, and by 1870 or 1880 the city was much larger.
} 
we infer sex), occupation, address, and signature literacy. The account ledgers record every deposit and withdrawal for the entire life of the account, as well as a balance after interest was added at the end of each year. There were 2,374 accounts in the 1850 signature book. We exclude from most of our analysis account holders identified as children, reducing the number of accounts for most purposes to $2,255 .^{29}$

The smaller "Linked 1850 Sample" consists of 641 adult account holders who were located in the 1850 census. ${ }^{30}$ We searched for all account holders who reported addresses in center-city Philadelphia (ward 1 and the four closest wards to the north and south). ${ }^{31}$ The 1850 census provides age, literacy, relationship to head of household, and the value of real property owned by the household. We rely on this smaller linked sample when information about age or relationship to the household head is required.

The data set is both cross sectional and longitudinal. Most of the information describing the account holder pertains to 1850 . Some of these attributes did not change over time (sex, date of birth), but some might have changed (occupation, address, literacy). We also have the complete history of the savings account (balances, deposits, withdrawals, and interest accruals) from 1850 until the account was closed. The information refers only to accounts opened in 1850 , however, and we do not know whether the same person opened another account at a later date.

Two features of the sample must be considered in the interpretation of the data. First, because all accounts in the sample were opened in 1850 , the number of accounts in our sample decreases for each year after 1850 as accounts were closed. Thus in each year we are observing the survivors of a process. The sample does not provide a cross section of PSFS accounts in 1850 or any other year, because most of the active accounts at any point in time were opened before or after 1850 . These data are best suited to showing the life cycles of accounts, but we can and will use them to make some inferences about aggregate behavior.

Second, our data show only one type of financial asset, savings at PSFS. For the individuals linked to the U.S. census we also have the

\footnotetext{
${ }^{29}$ Information on 27 accounts was lost because of a computer malfunction. In some tables we also exclude accounts that were closed after a long period of inactivity and appear to have been abandoned. We infer that account holders were children by the presence of terms like lad, girl, or the phrase "in trust for" in the column for occupation in the signature book.

${ }^{30} \mathrm{~A}$ total of 648 accounts were linked to the census, but at most, 7 are excluded because of missing information. It should be noted that the linkage rate is not 27 percent $(=648 / 2,374)$, but closer to 50 percent because we attempted to link only account holders living in the center portion of the city. PSFS account holders also lived in rural Pennsylvania, as well as parts of New Jersey and Delaware.

${ }^{31}$ Addresses were not given in the 1850 census but were added by the Philadelphia Social History Project (PSHP) to a photocopy of the manuscript census available at the University of Pennsylvania. The PSHP used city and business directories to find addresses. Although all city residents were not included in the directories, enough were listed to infer the addresses of most others under the (generally correct) assumption that census takers walked up and down city blocks in a predictable fashion.
} 
value of real estate, but very few account holders declared this form of wealth. ${ }^{32}$ Although we are able to look at only one form of liquid wealth, it is likely that, aside from cash, this was the only one being used. Ordinary Philadelphians in 1850 did not have many options when it came to savings banks. Only two such institutions were listed in the Philadelphia city and business directory for 1850: PSFS, centrally located on 6th Street, and the Western Savings Bank, located (not surprisingly) more westerly on 10th Street. By 1853 a third institution, the Savings Fund of the U.S. Company, located on 3rd Street and chartered in 1851, was listed. In 1854 the Saving Fund of the National Safety Trust Company began operations. The latter institution, and many of those advertising later in the $1850 \mathrm{~s}$, was aimed at the very small saver and had more convenient hours than PSFS. By 1855 the city and business directory reported seven savings banks in Philadelphia, but in 1850 PSFS was just about the "only game in town" for the relatively small saver.

\section{CHARACTERISTICS OF THE ACCOUNT HOLDERS AND THE ACCOUNTS}

\section{Account Holders}

Table 1 gives distributions by sex, age, occupation, and household relationship for account holders in the linked sample (the male occupation statistics come from the total sample). Almost 60 percent of the accounts opened in 1850 were held by females, and among these 40 percent were held by female servants. ${ }^{33}$ Female nonservants were most often in the 35- to 44-year age group when they began their accounts, but the accounts that survived the longest were opened by somewhat older women. The most common relation to household head for a female nonservant account holder was wife (40 percent), although wives' accounts had somewhat shorter durations than those of women who began their accounts as heads of households or as children. ${ }^{34}$ The

\footnotetext{
32 Just 28 of 642 adult account holders reported real property in the census, of whom 25 were males. The percentage of all adult males in the sample who were listed as owning real estate (25/260 $=9.6$ percent) is about the same as a weighted average of the ownership percentages by ethnicity in 1850. The Philadelphia Social History Project found substantial differences in real estate ownership by ethnicity in the 1850 census: 13 percent for native-born white men, 6 percent for Irish-born males, and 7 percent for German-born males (Hershberg and Williams, "Mulattoes and Blacks," p. 416). When these data are weighted by the distribution of places of birth in the PSFS linked sample, they yield an overall proportion owning real estate of 9 percent.

${ }^{33}$ Note that the figures from the linked sample are 59 percent and 40 percent, respectively, and that from the total sample they are 58 percent and 40 percent.

${ }^{34}$ Relationship to the household head was inferred from information on last name, age, and order on the census manuscripts. Not until 1880 did the U.S. federal population census inquire about relationship to household head. Some wives who had accounts were members of families who circumvented the upper limit on new accounts. This was clearly the case for those wives who opened their accounts precisely when their husbands did with exactly $\$ 200$, which was the upper limit for net accumulation in a particular year.
} 
TABLE

CHARACTERISTICS OF ACCOUNT HOLDERS BY LENGTH OF COMPLETED ACCOUNT AND SEX

(\% by length of completed account)

\begin{tabular}{|c|c|c|c|c|c|}
\hline & $\begin{array}{c}\text { All } \\
\text { Accounts }\end{array}$ & $\begin{array}{l}0<2 \\
\text { Years }\end{array}$ & $\begin{array}{l}2<5 \\
\text { Years }\end{array}$ & $\begin{array}{l}5<13 \\
\text { Years }\end{array}$ & $\begin{array}{c}\geq 13 \\
\text { Years }\end{array}$ \\
\hline \multicolumn{6}{|c|}{ Males } \\
\hline \multicolumn{6}{|l|}{ Age in 1850} \\
\hline $0-14$ & 6.8 & - & 4.6 & 25.9 & 3.8 \\
\hline $15-19$ & 7.2 & 9.3 & 6.2 & 3.7 & 7.7 \\
\hline $20-24$ & 14.1 & 16.1 & 13.8 & 11.1 & 11.5 \\
\hline $25-29$ & 19.4 & 17.8 & 23.1 & 18.5 & 19.2 \\
\hline $30-34$ & 14.4 & 15.3 & 15.4 & 9.3 & 19.2 \\
\hline $35-44$ & 18.6 & 21.2 & 20.0 & 11.1 & 19.2 \\
\hline $45-54$ & 11.8 & 10.2 & 10.8 & 18.5 & 7.7 \\
\hline $55-64$ & 4.9 & 5.9 & 6.2 & 1.9 & 3.8 \\
\hline \multirow[t]{2}{*}{$\geq 65$} & 2.7 & 4.2 & - & - & 7.7 \\
\hline & {$[263]^{\mathrm{a}}$} & [118] & [65] & [54] & [26] \\
\hline \multicolumn{6}{|l|}{ Relationship to head of household ${ }^{b}$} \\
\hline Head & 50.6 & 54.2 & 55.4 & 46.3 & 30.8 \\
\hline Wife & - & - & - & - & - \\
\hline Child & 19.8 & 14.4 & 18.5 & 35.2 & 15.4 \\
\hline Kin & 3.0 & 1.7 & 3.1 & 1.9 & 11.5 \\
\hline Servant & 5.3 & 4.2 & 9.2 & 1.9 & 7.7 \\
\hline \multirow[t]{2}{*}{ Unknown } & 21.3 & 25.4 & 13.8 & 14.8 & 34.6 \\
\hline & {$[263]^{\mathrm{a}}$} & {$[118]$} & {$[65]$} & {$[54]$} & [26]. \\
\hline \multicolumn{6}{|l|}{ Occupation (from signature book) ${ }^{c}$} \\
\hline Professional and managerial & 10.7 & 9.6 & 9.4 & 10.3 & 27.3 \\
\hline Trade and skilled & 36.7 & 38.7 & 36.5 & 35.2 & 23.6 \\
\hline Transportation and semiskilled & 34.9 & 37.0 & 30.6 & 37.9 & 27.3 \\
\hline Laborer & 12.7 & 10.2 & 17.3 & 13.1 & 12.7 \\
\hline Domestic service & 3.2 & 2.7 & 3.9 & 2.8 & 5.5 \\
\hline \multirow[t]{2}{*}{ No occupation } & 1.9 & 1.8 & 2.4 & 0.7 & 3.6 \\
\hline & {$[944]^{d}$} & [489] & [255] & {$[145]$} & [55] \\
\hline
\end{tabular}

Age in 1850
$0-14$
$15-19$
$20-24$
$25-29$
$30-34$
$35-44$
$45-54$
$55-64$
$\geq 65$
Relationship to head of household
Head
Wife
Child
Kin
Unknown

Female Nonservants

\begin{tabular}{rrrrr}
6.6 & 3.8 & 6.8 & 8.5 & 9.7 \\
4.4 & 6.3 & 1.7 & 5.1 & 3.2 \\
13.6 & 12.7 & 18.6 & 8.5 & 16.1 \\
16.2 & 26.6 & 15.3 & 6.8 & 9.7 \\
17.1 & 17.7 & 18.6 & 20.3 & 6.5 \\
21.1 & 16.5 & 22.0 & 27.1 & 19.4 \\
11.4 & 10.1 & 6.8 & 11.9 & 22.6 \\
7.9 & 6.3 & 10.2 & 6.8 & 9.7 \\
1.8 & - & - & 5.1 & 3.2 \\
& & & & \\
13.6 & 10.1 & 15.3 & 11.9 & 22.6 \\
39.9 & 45.6 & 42.4 & 40.7 & 19.4 \\
16.7 & 13.9 & 16.9 & 15.3 & 25.8 \\
4.4 & 5.1 & 1.7 & 6.8 & 3.2 \\
25.4 & 25.3 & 23.7 & 25.4 & 29.0 \\
{$[228]^{\mathrm{a}}$} & {$[79]$} & {$[59]$} & {$[59]$} & {$[31]$} \\
\hline
\end{tabular}


TABLE 1-continued

\begin{tabular}{|c|c|c|c|c|c|}
\hline & $\begin{array}{c}\text { All } \\
\text { Accounts }\end{array}$ & $\begin{array}{l}0<2 \\
\text { Years }\end{array}$ & $\begin{array}{l}2<5 \\
\text { Years }\end{array}$ & $\begin{array}{l}5<13 \\
\text { Years }\end{array}$ & $\begin{array}{l}\geq 13 \\
\text { Years }\end{array}$ \\
\hline \multicolumn{6}{|c|}{ Female Servants } \\
\hline \multicolumn{6}{|c|}{ Age in 1850} \\
\hline $0-14$ & - & - & - & - & - \\
\hline $15-19$ & 11.3 & 16.7 & 10.6 & 7.1 & 10.5 \\
\hline $20-24$ & 31.3 & 26.2 & 34.0 & 31.0 & 36.8 \\
\hline $25-29$ & 22.7 & 28.6 & 23.4 & 19.0 & 15.8 \\
\hline $30-34$ & 8.0 & 4.8 & 10.6 & 4.8 & 15.8 \\
\hline $35-44$ & 17.3 & 19.0 & 14.9 & 21.4 & 10.5 \\
\hline $45-54$ & 6.6 & - & 6.4 & 11.9 & 5.3 \\
\hline $55-64$ & - & - & - & - & 一 \\
\hline \multirow[t]{2}{*}{$\geq 65$} & 3.3 & 4.7 & - & 4.8 & 5.3 \\
\hline & {$[150]^{\mathrm{a}}$} & {$[42]$} & [47] & {$[42]$} & [19] \\
\hline
\end{tabular}

${ }^{a}$ Number of observations, Linked 1850 Sample only, appears in brackets.

b Relationship to head of household was inferred from information on last name, age, and order on census form.

${ }^{c}$ Occupations are given for adult males only; too few female nonservants listed occupations. Professional and managerial includes: clergy, lawyers, physicians, teachers, bookkeepers, agents, landlords, manufacturers, and clerks. Trade and skilled includes: boardinghouse keepers, grocers, hucksters, shopkeepers, tavernkeepers, employees in trade, blacksmiths, carpenters, and printers. Transportation and semiskilled includes: seamen, teamsters, police officers, machinists, weavers, and operatives.

d Number of observations, 1850 Sample only, appears in brackets.

Sources: PSFS Accounts, Linked 1850 Sample and 1850 Sample.

female servants were generally in the 20 - to 24 -year old age group when they began their accounts, and there is little discernible change in their age distribution across the duration classes. Most opened their accounts, it seems, when they found their first employment. ${ }^{35}$

The majority of males were heads of household (51 percent). The unknown relationship category is large for both males and female nonservants (about 20 percent for each), and most of these were probably boarders. Nearly half of all adult male account holders were professionals, managers, in retail trade, or skilled craftsmen.

In some ways, those who opened accounts at PSFS in 1850 were quite representative of the total population from which they were drawn. In other ways, they were atypical. Comparisons between the PSFS accounts and the federal population census can be made regarding occupation and ethnicity.

The occupational distribution for males with accounts at PSFS is similar to that for all male Philadelphians, though skilled and semiskilled workers were somewhat overrepresented and laborers were underrep-

\footnotetext{
${ }^{35}$ Among the women whom we coded as servants, 87 percent lived in the households of others. That is, the vast majority of female servants boarded with their employers. Not surprisingly, two-thirds of the female servants were born in Ireland. Because most came to the United States in their early twenties, it seems reasonable, from the age distribution, that they opened their PSFS accounts soon after they obtained their first job in America.
} 
resented in the accounts. ${ }^{36}$ The large number of female servants among PSFS account holders is very different from the general population. Servants were 40 percent of all females who opened accounts but were probably not more than 10 percent of all adult women in the city. ${ }^{37}$

Ethnicity comparisons are necessarily crude because we only have census data for the county of Philadelphia, not for the central parts of the city in which most PSFS account holders lived. From this information it appears that the foreign-born, especially the Irish, were substantially overrepresented among account holders, though this may be misleading, because the Irish were more likely to live in the central wards of the city. The preponderance of Irish account holders owed only in part to the large number of Irish female servants who held accounts. ${ }^{38}$

Account holders at PSFS were not entirely representative of the population of Philadelphians in 1850, nor would we expect them to be. But the linked group appears to be an unbiased sample of the entire group of accounts opened in 1850 in several dimensions. Nearly identical percentages exist for the two data sets with regard to the three main groups-males, female nonservants, and female servants-and the occupational percentages for males are similar across the two groups. The distribution of account durations for males is somewhat more

\footnotetext{
${ }^{36}$ The distribution of occupations among adult male PSFS account holders and from the 1860 federal population census for adult males in Philadelphia is

\begin{tabular}{lcc} 
& PSFS & 1860 Census \\
\cline { 2 - 3 } Professional and managerial & $10.7 \%$ & $10.0 \%$ \\
Trade and skilled & 36.7 & 31.8 \\
Transportation and semiskilled & 34.9 & 31.2 \\
Laborer & 12.7 & 22.9 \\
Domestic service & 3.2 & 2.1 \\
No occupation & 1.9 & 1.9
\end{tabular}
}

Source: Occupational breakdown from the 1860 census is computed from Hershberg, et al., "Occupation," p. 178.

${ }^{37}$ Occupational breakdowns are not available for women in the 1850 census. In 1870 , domestic servants were 7.8 percent of all women ten years of age and older, in Philadelphia (U.S. Bureau of the Census, Ninth Census, pp. 598, 768) and were 9.8 percent of all female urban dwellers in the United States (computed from Rotella, From Home to Office, pp. 10, 33).

${ }^{38}$ The ethnic distributions of PSFS account openers (from the linked sample) and of the residents of Philadelphia county were

\begin{tabular}{|c|c|c|c|c|c|}
\hline & \multicolumn{4}{|c|}{ PSFS } & \multirow[t]{2}{*}{1850 Census, County of Philadelphia } \\
\hline & All & Males & $\begin{array}{c}\text { Female } \\
\text { Nonservants }\end{array}$ & Female Servants & \\
\hline Native-born & $39.7 \%$ & $39.0 \%$ & $54.3 \%$ & $19.7 \%$ & $70.2 \%$ \\
\hline Irish & 39.7 & 34.7 & 26.2 & 67.1 & 17.7 \\
\hline German & 8.0 & 12.3 & 5.0 & 5.9 & 5.6 \\
\hline Others & 12.6 & 14.0 & 14.5 & 7.2 & 5.6 \\
\hline
\end{tabular}

Sources: PSFS Accounts, 1850 sample; and U.S. Bureau of the Census, Compendium of the Seventh Census, p. 399. 
skewed to the right in the linked sample, although those for female servants and female nonservants are very similar in the two data sets.

Most accounts begun in 1850 were brief in duration. Fully 42 percent, across all groups, closed within two years (see number of observations, Table 2). Although 30 percent lasted at least five years, just 14 percent of the accounts extended beyond ten years. ${ }^{39}$ Brief account histories in the PSFS records do not necessarily imply that asset accumulation ceased for those who closed accounts. Rather, the data are consistent with an interpretation that many account holders, when they closed their accounts, moved resources to other assets, although we cannot be certain of this.

Longer accounts, as shown in Table 1, were disproportionately held by those who opened accounts as children, by women (especially servants), and by men and women with unknown relationship to the head of household. Almost 40 percent of all the accounts opened by female servants in 1850 lasted for at least five years, and 20 percent lasted for at least ten years. Male heads of household and males in general had relatively brief accounts. Fully one-half of all accounts opened by adult males closed before two years, whereas only 29 percent of those opened by female servants did. The fact that among men, the most stable and settled group-male heads of household-had the briefest accounts, whereas the apparently least-settled group-probably boarders-had the longest accounts, suggests that the closing of an account may have often involved moving funds to other assets, rather than drawing it down to meet exigencies. Various aspects of the accounts, to be detailed later, suggest they were not used primarily for "precautionary saving" - that is, to smooth consumption over the short run. Male account holders in particular appear to have used the accounts to amass sufficient funds to purchase another asset, sometimes business property.

\section{Accounts: The Long and the Short of It}

Summary information on central tendencies among balances, deposits, and withdrawals is provided in Table 2 for adult males, adult females who were not servants, and female servants by eventual length of account. An immediately obvious aspect of the accounts is their magnitude. We should note at the outset that all dollar values in the tables and text are expressed in $\mathbf{1 8 5 0}$ dollars. For brief accounts (up to two-years duration), average balances for males were $\$ 74$ or about one-quarter annual income for laborers, whereas accounts of medium duration (two to under five years) were $\$ 151$, or just over one-half

\footnotetext{
${ }^{39}$ Although withdrawals increased in 1854 and 1857 , accounts did not close with more frequency in those years. They did, however, close disproportionately more in 1861 . Our sample, however, is rather small by the Civil War, and thus the distribution of account lengths is probably not much affected by the war. We cannot investigate the separate roles of duration and year because all of our accounts began in 1850 .
} 
TABLE 2

CHARACTERISTICS OF THE ACCOUNTS, BY LENGTH OF COMPLETED ACCOUNT AND SEX

\begin{tabular}{|c|c|c|c|c|c|c|c|}
\hline & $\begin{array}{c}\text { All } \\
\text { Accounts }\end{array}$ & $\begin{array}{l}0<2 \\
\text { Years }\end{array}$ & $\begin{array}{l}2<5 \\
\text { Years }\end{array}$ & $\begin{array}{l}5<10 \\
\text { Years }\end{array}$ & $\begin{array}{l}10<15 \\
\text { Years }\end{array}$ & $\begin{array}{c}15<20 \\
\text { Years }\end{array}$ & $\begin{array}{r}\geq 20 \\
\text { Years }\end{array}$ \\
\hline \multicolumn{8}{|c|}{ Balances } \\
\hline \multicolumn{8}{|c|}{ Average balance (median, \$) } \\
\hline Males & 108 & 74 & 151 & 186 & 210 & 189 & 232 \\
\hline Female nonservants & 98 & 60 & 101 & 121 & 147 & 142 & 130 \\
\hline Female servants & 68 & 39 & 62 & 85 & 92 & 100 & 282 \\
\hline \multicolumn{8}{|c|}{ Maximum balance (median, \$) } \\
\hline Males & 161 & 100 & 221 & 301 & 421 & 393 & 703 \\
\hline Female nonservants & 151 & 79 & 164 & 215 & 304 & 307 & 382 \\
\hline Female servants & 111 & 46 & 106 & 129 & 191 & 180 & 637 \\
\hline \multicolumn{8}{|c|}{ Deposits } \\
\hline \multicolumn{8}{|l|}{$\begin{array}{l}\text { Amount of first deposit } \\
\text { (median, \$) }\end{array}$} \\
\hline Males & 50 & 50 & 70 & 78 & 100 & 50 & 50 \\
\hline Female nonservants & 50 & 50 & 50 & 50 & 51 & 50 & 50 \\
\hline Female servants & 30 & 25 & 30 & 35 & 35 & 30 & 50 \\
\hline \multicolumn{8}{|c|}{$\begin{array}{l}\text { Average deposit, excluding } \\
\text { first (median, \$) }\end{array}$} \\
\hline Males & 24 & 17 & 30 & 34 & 38 & 25 & 47 \\
\hline Female nonservants & 24 & 14 & 25 & 31 & 24 & 35 & 34 \\
\hline Female servants & 14 & 10 & 14 & 15 & 16 & 15 & 29 \\
\hline \multicolumn{8}{|c|}{$\begin{array}{l}\text { Deposits per year (median), } \\
\text { excluding first }^{\mathrm{a}}\end{array}$} \\
\hline Males & 1.00 & 1.30 & 0.96 & 0.98 & 0.63 & 1.36 & 0.59 \\
\hline Female nonservants & 0.75 & 1.13 & 0.84 & 0.62 & 0.72 & 0.43 & 0.46 \\
\hline Female servants & 0.72 & 0.73 & 0.88 & 0.68 & 0.79 & 0.53 & 0.56 \\
\hline \multicolumn{8}{|c|}{ Withdrawals } \\
\hline \multicolumn{8}{|c|}{$\begin{array}{l}\text { Average withdrawal, excluding } \\
\text { last (median, \$) }\end{array}$} \\
\hline Males & 50 & 30 & 50 & 64 & 78 & 78 & 82 \\
\hline Female nonservants & 35 & 25 & 30 & 42 & 59 & 49 & 45 \\
\hline Female servants & 22 & 15 & 20 & 25 & 31 & 21 & 47 \\
\hline \multicolumn{8}{|c|}{$\begin{array}{l}\text { Withdrawals per year } \\
\text { (median), excluding last }{ }^{\mathrm{a}}\end{array}$} \\
\hline Males & 0.19 & $0.0^{\mathrm{b}}$ & 0.22 & 0.27 & 0.29 & 0.42 & 0.24 \\
\hline Female nonservants & 0.20 & $0.0^{\mathrm{b}}$ & 0.25 & 0.23 & 0.27 & 0.25 & 0.28 \\
\hline Female servants & 0.15 & $0.0^{\mathrm{b}}$ & $0.0^{\mathrm{b}}$ & 0.14 & 0.18 & 0.23 & 0.29 \\
\hline \multicolumn{8}{|c|}{$\begin{array}{l}\text { Amount of last withdrawal } \\
\text { (median, \$) }\end{array}$} \\
\hline Males & 104 & 82 & 162 & 168 & 113 & 109 & 89 \\
\hline Female nonservants & 86 & 61 & 103 & 95 & 137 & 137 & 82 \\
\hline Female servants & 77 & 41 & 71 & 98 & 119 & 137 & 261 \\
\hline \multicolumn{8}{|c|}{ Number of Observations (for balance) and Percentage of Group } \\
\hline \multicolumn{8}{|l|}{ Males } \\
\hline$N$ & 944 & 489 & 255 & 116 & 39 & 19 & 26 \\
\hline$\%$ & 100 & 52 & 27 & 12 & 4 & 2 & 3 \\
\hline \multicolumn{8}{|l|}{ Female nonservants } \\
\hline$N$ & 783 & 307 & 214 & 143 & 56 & 24 & 39 \\
\hline$\%$ & 100 & 39 & 27 & 18 & 7 & 3 & 5 \\
\hline
\end{tabular}


TABLE 2-continued

\begin{tabular}{lcrrrrrr}
\hline \hline & $\begin{array}{c}\text { All } \\
\text { Accounts }\end{array}$ & $\begin{array}{r}0<2 \\
\text { Years }\end{array}$ & $\begin{array}{r}2<5 \\
\text { Years }\end{array}$ & $\begin{array}{r}5<10 \\
\text { Years }\end{array}$ & $\begin{array}{r}10<15 \\
\text { Years }\end{array}$ & $\begin{array}{r}15<20 \\
\text { Years }\end{array}$ \\
\hline $\begin{array}{l}\text { Female servants } \\
N\end{array}$ & 527 & 153 & 168 & 101 & 51 & 18 & 36 \\
$\%$ & 100 & 29 & 32 & 19 & 10 & 3 & 7 \\
\hline
\end{tabular}

a Figures exclude the first six months of the account and accounts open for less than six months. b The median number of withdrawals per year, excluding the last, is zero.

Notes: Dollar values are deflated using the Hoover consumer price index, 1851 to 1880 , for which $1850=100$ (U.S. Bureau of the Census, Historical Statistics of the United States, series E-174). The 1850 figure is extrapolated on the Bezanson series for Philadelphia (U.S. Bureau of the Census, Historical Statistics of the United States, series F-97). Where possible, children have been excluded (for example, lad, girl, boy).

Source: PSFS Accounts, 1850 Sample.

annual income. ${ }^{40}$ Maximum balances for accounts of two to under five years were $\$ 221$, or eight-tenths annual income. The income of female servants was far lower than that of even low-skilled males, and much of it was in the form of in-kind transfers of housing and food. The average balance and maximum balance of a female servant account holder were about three-quarters that of an average male across the range of occupations. Female servants who established an account appear to have saved a considerable fraction of their wages. If, as we believe was the case, the discretionary income of a servant was one dollar per week, the brief accounts contained three-quarters of a year's income. ${ }^{41}$

In general, accounts began life with similar values independent of how long they lasted. Initial deposits averaged $\$ 50$ for female nonservants and $\$ 30$ for female servants (see Table 2). Men began their accounts with about $\$ 50$, although accounts lasting from 2 to 15 years began with more, $\$ 70$ to $\$ 100$. Subsequent deposits were somewhat less than half the initial amount for all three groups and increased with the length of the account. Thus the subsequent median deposit for a male account holder was $\$ 30$ to $\$ 40$ for accounts lasting 2 to 15 years and $\$ 15$ for a similar account held by a female servant. The median withdrawal (excluding the last) was somewhat larger than the median deposit (excluding the first). Among men with accounts lasting in the five-toten-year range, it was $\$ 64$; for the female nonservants it was $\$ 42$; and for

\footnotetext{
${ }^{40}$ A recent study of wages paid to civilians hired by the U.S. Army reveals that the daily wage in 1850 for laborers was \$1.075; for artisans \$1.434; and for clerks $\$ 2.352$ (Goldin and Margo, "Wages"). Most account holders were in either the laborer or artisan group. The question, then, is how many days per year a laborer or artisan could expect to find work. If the working year were ten months long and each month contained 26 working days, annual income for a laborer would have been $\$ 280$ in 1850 . It should be noted, however, that many of the account holders were self-employed, and we have no way of knowing what their annual incomes were, other than to appeal to labor market equilibrium. Median balances, deposits, and withdrawals did not differ greatly among adult males by occupation, with the exception that laborers had smaller deposits.

${ }^{41}$ Lebergott reports an average wage of 80 cents per week for servants in Pennsylvania in 1850, (Lebergott, Manpower, appendix table A6, p. 542). It is not unreasonable, therefore, for the weekly payment in Philadelphia to have been one dollar.
} 
the servants it was $\$ 25$. Thus withdrawals were about one and one-half times as large as the average deposit.

To understand how accumulation took place, when it did, one must also look at the number of deposits and withdrawals per year. Adult males whose accounts lasted two to five years made a deposit about once a year (in addition to the first deposit), whereas withdrawals for those accounts occurred only once every four to five years. That is, an account lasting four years would have been added to four times and subtracted from once, prior to its closing.

Both groups of women made deposits about once every 14 months for accounts lasting two to five years. Withdrawals by servants, however, were made less often. The median number of withdrawals per year was zero for servants, although they occurred once every four years for the nonservant females. For all three subgroups, then, accounts were not very active and became somewhat less active with time, particularly with regard to deposits.

Even an inactive account will eventually be closed. Final withdrawals were in amounts that greatly exceeded average withdrawals-often three times the amount-suggesting, but not establishing, that funds were shifted to alternative uses rather than being drawn down to cover expenditures or meet payments. Note that we have no direct evidence from the account records concerning whether the account was closed because of a move from the Philadelphia area or because of death. As we noted before, accounts of the more geographically stable groups were briefer than were those of the more unstable, such as boarders, and thus we believe that the majority of accounts closed because individuals shifted funds into other assets (for example, property).

We have some evidence on this score, although from a small number of cases. City and business directories for Philadelphia were published annually during the 1850 s. By tracing account holders who closed their accounts, we can see if they exited the directory or purchased additional property. Because these directories, like today's phone books, could have been a year or so out of date, we employ the rule that movement out of the directory just before or in a period of two years after the account was closed constitutes leaving the city, and a purchase of property within two years of closing the account constitutes evidence of the use of the funds. We also limited our attention to accounts that were closed before 1857 and to male heads of households, the only group routinely covered in the directories.

We searched for 41 male heads of households in the city directories. Of these, we found 32 names (78 percent) at least once. The remaining 22 percent could have escaped the attention of the directory or left town too soon after their arrival to be counted. Of the 32 we did find, 22 percent (or 7) left town sometime just before or after they closed their account, 38 percent (or 12) had a change of address, and 22 percent (or 
7 of the 12) had listings that suggest they purchased real estate; that is, they acquired an additional address or expanded into a neighboring lot. Thus, few of those who closed their accounts did so because they left town, and at least an equal number and perhaps considerably more were engaged in some type of transfer of funds into real estate. We do not have a compelling story for the remaining 13 of the 32 accounts we traced, but the purchase of a horse, a carriage, or a piece of machinery would not be apparent in the directories we have consulted. We find this small amount of evidence to be compelling and to suggest that, at least for many of the male heads of households, the bank provided a means of storing and accumulating funds for the purchase of physical assets.

Our point is that final withdrawals differed so greatly from withdrawals that did not close the account that it seems unlikely that month-tomonth exigencies were responsible for most account closings. ${ }^{42} \mathrm{Simi}$ larly, because the initial deposit was about twice as large as subsequent deposits for all but the very longest accounts, many account holders already had substantial accumulations and thus may have been shifting between assets when they opened the account. ${ }^{43}$

\section{The Life Cycle of Accounts and Life-Cycle Savings}

Two aspects of the life cycle are of interest here-those relating to the account and those to the individual. Those concerning the account are summarized in Table 3, in which median balances, deposits, and withdrawals are given in intervals by eventual length of account. Note that the column headings of the table refer to the length of the completed account, whereas the row headings refer to the interval of the account. Thus, for example, we can refer to activity in the third year of an account that was closed ten years after it opened. This mode of presentation enables one to observe how account behavior changed over the course of the account, given its eventual length. One can see whether accounts that were closed early differed in their deposit (or balance or withdrawal) histories from those that lasted a long time.

Independent of the eventual length of the account, accumulation appears to have taken place for the first several years. (Note that this can be seen by looking down the columns; for each length of completed

\footnotetext{
42 Simulation models as in Deaton, "Saving," would be needed to establish this point more formally and forcefully. If account holders were saving for precautionary reasons, the amount of the final withdrawal would, by necessity, be greater on average than previous withdrawals. That is, if an individual's income were subject to stochastic shocks, savings would be used every now and then to smooth consumption. A series of bad draws (for example, spells of unemployment) or one considerably bad one (for example, one long spell of unemployment) could cause the individual to reduce the account to zero and be forced to close it. Thus, the final withdrawal would, on average, have to be larger than the previous ones. But final withdrawals in the PSFS accounts seem, to our eye, to be larger than ones consistent with a model of precautionary savings.

${ }^{43}$ Although female servants were probably not shifting funds between assets, the fact that they began their accounts with $\$ 30$ reveals that they had accumulated funds for some time before opening their accounts.
} 
TABLE 3

THE LIFE CYCLE OF ACCOUNTS: ACCOUNT CHARACTERISTICS BY LENGTH OF COMPLETED ACCOUNT AND INTERVAL, FOR MALES, FEMALE NONSERVANTS, AND FEMALE SERVANTS

(in constant dollars, $1850=100$ )

\begin{tabular}{|c|c|c|c|c|c|c|c|}
\hline $\begin{array}{l}\text { Interval within } \\
\text { Account History }\end{array}$ & $\begin{array}{c}\text { All } \\
\text { Accounts }\end{array}$ & $\begin{array}{l}0<2 \\
\text { Years }\end{array}$ & $\begin{array}{l}2<5 \\
\text { Years }\end{array}$ & $\begin{array}{l}5<10 \\
\text { Years }\end{array}$ & $\begin{array}{c}10<15 \\
\text { Years }\end{array}$ & $\begin{array}{c}15<20 \\
\text { Years }\end{array}$ & $\begin{array}{r}\geq 20 \\
\text { Years }\end{array}$ \\
\hline \multicolumn{8}{|c|}{ Average Balance (median) } \\
\hline \multicolumn{8}{|l|}{ Males } \\
\hline $0<1$ year & 90 & 70 & 101 & 101 & 113 & 80 & 98 \\
\hline $1<2$ & 136 & 103 & 146 & 144 & 200 & 122 & 135 \\
\hline $2<4$ & 193 & & 171 & 211 & 239 & 216 & 223 \\
\hline $4<6$ & 202 & & 200 & 188 & 228 & 210 & 221 \\
\hline $6<9$ & 180 & & & 194 & 174 & 170 & 202 \\
\hline $9<12$ & 188 & & & 189 & 220 & 222 & 162 \\
\hline $12<15$ & 162 & & & & 317 & 157 & 150 \\
\hline $15<18$ & 100 & & & & & 79 & 147 \\
\hline \multirow{2}{*}{$18<20$} & 216 & & & & & $(278)^{\mathrm{a}}$ & 200 \\
\hline & {$[944]^{b}$} & [489] & {$[255]$} & [116] & [39] & [19] & [26] \\
\hline \multicolumn{8}{|l|}{ Female nonservants } \\
\hline $0<1$ year & 74 & 57 & 84 & 93 & 69 & 76 & 100 \\
\hline $1<2$ & 102 & 64 & 103 & 113 & 94 & 101 & 134 \\
\hline $2<4$ & 116 & & 104 & 128 & 137 & 124 & 135 \\
\hline $4<6$ & 115 & & 103 & 114 & 130 & 111 & 147 \\
\hline $6<9$ & 118 & & & 101 & 155 & 118 & 112 \\
\hline $9<12$ & 161 & & & 91 & 175 & 189 & 123 \\
\hline $12<15$ & 105 & & & & 95 & 126 & 83 \\
\hline $15<18$ & 88 & & & & & 118 & 69 \\
\hline \multirow{2}{*}{$18<20$} & 102 & & & & & 241 & 86 \\
\hline & [783] & [307] & [214] & {$[143]$} & {$[56]$} & [24] & [39] \\
\hline \multicolumn{8}{|l|}{ Female servants } \\
\hline $0<1$ year & 43 & 36 & 46 & 45 & 45 & 35 & 58 \\
\hline $1<2$ & 62 & 51 & 62 & 67 & 67 & 54 & 71 \\
\hline $2<4$ & 82 & & 72 & 86 & 76 & 81 & 108 \\
\hline $4<6$ & 99 & & 123 & 96 & 95 & 91 & 118 \\
\hline $6<9$ & 109 & & & 105 & 99 & 101 & 183 \\
\hline $9<12$ & 149 & & & 96 & 133 & 138 & 194 \\
\hline $12<15$ & 143 & & & & 64 & 115 & 161 \\
\hline $15<18$ & 173 & & & & & 108 & 217 \\
\hline \multirow[t]{2}{*}{$18<20$} & 317 & & & & & & 317 \\
\hline & [527] & [153] & [168] & [101] & [51] & [18] & [36] \\
\hline \multicolumn{8}{|c|}{ Average Deposit, Excluding First (median) } \\
\hline \multicolumn{8}{|l|}{ Males } \\
\hline $0<1$ year & 24 & 20 & 25 & 30 & 19 & 12 & 30 \\
\hline $1<2$ & 32 & 29 & 40 & 31 & 35 & 25 & 41 \\
\hline $2<4$ & 39 & & 39 & 39 & 43 & 22 & 37 \\
\hline $4<6$ & 35 & & 28 & 44 & 30 & 21 & 50 \\
\hline $6<9$ & 44 & & & 45 & 62 & 17 & 44 \\
\hline $9<12$ & 40 & & & & 45 & 14 & 46 \\
\hline $12<15$ & 51 & & & & (38) & 49 & 52 \\
\hline $15<18$ & 24 & & & & & (21) & 52 \\
\hline $18<20$ & 26 & & & & & & 26 \\
\hline \multicolumn{8}{|l|}{ Female nonservants } \\
\hline $0<1$ year & 21 & 17 & 25 & 24 & 25 & 22 & 38 \\
\hline $1<2$ & 25 & 20 & 28 & 26 & 30 & 25 & 40 \\
\hline
\end{tabular}


TABLE 3-continued

\begin{tabular}{lccccccr}
\hline \hline $\begin{array}{c}\text { Interval within } \\
\text { Account History }\end{array}$ & $\begin{array}{c}\text { All } \\
\text { Accounts }\end{array}$ & $\begin{array}{c}0<2 \\
\text { Years }\end{array}$ & $\begin{array}{c}2<5 \\
\text { Years }\end{array}$ & $\begin{array}{c}5<10 \\
\text { Years }\end{array}$ & $\begin{array}{c}10<15 \\
\text { Years }\end{array}$ & $\begin{array}{r}15<20 \\
\text { Years }\end{array}$ & $\begin{array}{r}\geq 20 \\
\text { Years }\end{array}$ \\
\hline $\begin{array}{l}\text { Female nonservants } \\
\text { (continued) }\end{array}$ & & & & & & & \\
$2<4$ & 32 & & 33 & 36 & 28 & 24 & 49 \\
$4<6$ & 35 & & 31 & 42 & 27 & 23 & 38 \\
$6<9$ & 34 & & & 32 & 28 & 45 & 30 \\
$9<12$ & 37 & & & & 37 & 46 & 34 \\
$12<15$ & 34 & & & & & $(34)$ & 40 \\
$15<18$ & 26 & & & & & $(36)$ & 24 \\
$18<20$ & 35 & & & & & & 33 \\
Female servants & & & & & & & \\
$0<1$ year & 14 & 12 & 15 & 15 & 15 & 11 & 20 \\
$1<2$ & 15 & 14 & 15 & 15 & 18 & 15 & 22 \\
$2<4$ & 17 & & 16 & 17 & 18 & 16 & 21 \\
$4<6$ & 18 & & 18 & 17 & 18 & 13 & 25 \\
$6<9$ & 18 & & & 18 & 16 & 16 & 26 \\
$9<12$ & 23 & & & & 18 & 16 & 28 \\
$12<15$ & 20 & & & & $(10)$ & 13 & 23 \\
$15<18$ & 22 & & & & & $(13)$ & 25 \\
$18<20$ & 32 & & & & & & 33
\end{tabular}

Average Withdrawal, Excluding Last (median)

\begin{tabular}{|c|c|c|c|c|c|c|c|}
\hline \multicolumn{8}{|l|}{ Males } \\
\hline $0<1$ year & 35 & 31 . & 50 & 99 & & & \\
\hline $1<2$ & 46 & 35 & 40 & 51 & (17) & & (75) \\
\hline $2<4$ & 61 & & 59 & 54 & 57 & (71) & 135 \\
\hline $4<6$ & 56 & & 79 & 51 & 39 & 60 & 82 \\
\hline $6<9$ & 56 & & & 55 & 28 & (90) & 92 \\
\hline $9<12$ & 61 & & & & 57 & (62) & 68 \\
\hline $12<15$ & 49 & & & & (29) & (65) & 49 \\
\hline $15<18$ & 52 & & & & & (33) & 60 \\
\hline $18<20$ & 71 & & & & & & (95) \\
\hline \multicolumn{8}{|c|}{ Female nonservants } \\
\hline $0<1$ year & 25 & 25 & 25 & 47 & (30) & & (25) \\
\hline $1<2$ & 28 & 28 & 25 & 29 & (50) & (57) & 25 \\
\hline $2<4$ & 32 & & 28 & 43 & 34 & 28 & 68 \\
\hline $4<6$ & 37 & & 24 & 32 & 87 & (17) & 51 \\
\hline $6<9$ & 28 & & & 23 & 39 & 46 & 29 \\
\hline $9<12$ & 28 & & & & 48 & 27 & 28 \\
\hline $12<15$ & 33 & & & & (24) & 29 & 49 \\
\hline $15<18$ & 63 & & & & & (48) & 78 \\
\hline $18<20$ & 38 & & & & & & 34 \\
\hline \multicolumn{8}{|c|}{ Female servants } \\
\hline $0<1$ year & 16 & 15 & 20 & (15) & (22) & & \\
\hline $1<2$ & 20 & 19 & 17 & 25 & (25) & & \\
\hline $2<4$ & 20 & & 20 & 19 & 18 & (13) & 17 \\
\hline $4<6$ & 19 & & 15 & 24 & 18 & (15) & 23 \\
\hline $6<9$ & 22 & & & 55 & 19 & (20) & 21 \\
\hline $9<12$ & 31 & & & & 36 & 26 & 28 \\
\hline $12<15$ & 15 & & & & & (7) & 16 \\
\hline $15<18$ & 22 & & & & & 17 & 26 \\
\hline $18<20$ & 38 & & & & & & 38 \\
\hline
\end{tabular}


TABLE 3-continued

\footnotetext{
a The numbers in parentheses are for cells with fewer than ten observations but more than three. Cells with fewer than four observations are not shown.

b The number of observations is in brackets.

Notes: Dollar values are deflated using the Hoover consumer price index, 1851 to 1880 , for which $1850=100$ (U.S. Bureau of the Census, Historical Statistics of the United States, series E-174). The 1850 figure is extrapolated on the Bezanson series for Philadelphia (U.S. Bureau of the Census, Historical Statistics of the United States, series F-97). The intervals include the lower bound and exclude the upper bound, for example; $2-4$ is two years exactly to just under five years. Where possible, children have been excluded (for example, lad, girl, boy).

Source: PSFS Accounts, 1850 Sample.
}

account; the median balance rises to about year two or three in duration.) Accounts of males and female nonservants then reached a plateau and subsequently declined in magnitude. The median account for males rose to a bit less than a year of gross income in 1850 (about $\$ 220$ ), also independent of the eventual length of the account. The female servant accounts are characterized by considerably more continued, albeit slow, accumulation over their lifetimes. Their average balances rose to about $\$ 130$ for accounts lasting 10 to 20 years, and even greater for the very long accounts. The accumulation behavior of the female nonservants falls somewhere in between. The female nonservants were a heterogeneous group, and in the full sample we cannot distinguish the wives from the heads of household.

Long and short accounts of from 2 to 15 years in eventual duration did not differ greatly or systematically early in their lives. We have already made this point with regard to the initial deposit, and a similar conclusion can be reached for median balances, deposits, and withdrawals by reading across the rows of Table 3 . There are some exceptions, but generally there is little to distinguish the long-duration accounts from the brief ones. We are not certain why longer accounts cannot be distinguished from the shorter ones early in their lives. One possibility is that part of the process that generated long and short accounts was random and that the longer ones belonged to fortunate individuals whose bank accounts survived the various shocks to income over the lifetime of the account (and the person).

Given the detail we present in Tables 2 and 3 on the account holders and the accounts, we can easily characterize the median saver and the process of accumulation and deaccumulation. Consider a male account holder whose account lasted four years. His account began with $\$ 70$, deposits were made about once a year, and withdrawals were much less frequent. Deposits were about $\$ 40$ or more than half the initial amount, with the exception of the first year when they were less. Withdrawals were, on average, about seven-tenths of the initial deposit, or $\$ 50$. Accounts at PSFS were interest bearing and accrued interest at the rate 
of 4 to 5 percent during most of the period we are considering. ${ }^{44}$ Using the numbers for the median account for males in the sample, an account that lasted four years would have accumulated about $\$ 182 .{ }^{45}$ Final withdrawals were for approximately that amount $(\$ 162)$, as can be seen with reference to Table 2 . The accounts did not mount and then decline slowly. Nor did they typically rise and fall with some frequency. Rather, they mounted and were then terminated. Thus the typical male PSFS saver added to his account infrequently but regularly, dipped into it rarely but for not inconsiderable sums, and closed it by withdrawing a rather substantial sum of money.

Our depiction of the median adult-male saver (female nonservants were similar) implies that many used other forms of asset holding and credit. Their accounts at PSFS were not counterparts to modern-day checking accounts. Rather, they were more like money-market accounts. Account holders may have accumulated cash in cookie jars and mattresses, and when the cash reserve reached some target level, possibly having been drawn down several times in the interim, it was carted off to the bank. We find no evidence that the bank discouraged people from bringing in relatively small sums, and there are many entries for deposits under $\$ 5.00$. Similarly, the infrequency of withdrawals suggests that when funds were tight, our savers must have been extended credit by the landlord, grocery store, tavern, friends, and family, and used the local pawnshop. At some time accounts had to be settled, sending the saver back to PSFS to withdraw what appears to be a very large sum of money. ${ }^{46}$

Savers, it seems, were not withdrawing amounts to tide them over for a few weeks or a month at a time. Rather, they were withdrawing two to three months of average gross income, just as they were depositing one to two months of average gross income. These withdrawals, of course, could just as well have been used for large purchases or to meet payments on a mortgage. It seems clear from the regularity of withdrawals from some accounts that some savers were using these funds to

${ }^{44}$ Interest paid by PSFS, as given in the records of the bank, accrued at the rate of:

$\begin{array}{ll}1850-1855 & 4.0 \% \\ 1856-1858 & 4.8 \\ 1859-1863 & 5.4 \\ 1864-1879 & 4.8 \\ 1880 & 4.0 \\ 1881-1882 & 3.0\end{array}$

\footnotetext{
45 The typical male saver is assumed to begin with $\$ 70$ and to add $\$ 25$ during year one, $\$ 40$ in year two, $\$ 39$ in year three, and $\$ 28$ in year four. A withdrawal of $\$ 50$ also occurs during year four, and the account is closed at the end of that year. Allowing for a 5 percent interest rate results in an accumulation of $\$ 182$ at the end of the four years. Although it may seem odd for someone to have withdrawn funds in the same year he closed the account, there were many accounts in which precisely that occurred.

${ }^{46}$ This reckoning could have been institutionalized as part of the new year. We do observe more account activity in January than during any other month.
} 
repay loans. On the basis of the information at hand, we cannot distinguish between withdrawals to meet exigencies from those to meet scheduled payments. We speculate that target savers withdrew larger sums than precautionary savers, and thus the pattern described above suggests, but does not prove, the predominance of target saving.

The infrequency of both deposits and withdrawals could have resulted from high transaction costs, but we find no evidence to support such speculation, although there may have been long lines on certain days and at certain times. Virtually all account holders in the linked sample lived within walking distance of the bank and many lived within a few blocks. The bank's hours were Monday and Thursday from 9 A.M. to 1 P.M. and again from 3 to 7 P.M.; it was, therefore, open 20 hours a week in 1850, and somewhat more later in the decade. We do not know how many bank clerks handled business during these hours, and we suspect, but are not certain, that a special window was set aside for opening and closing accounts. ${ }^{47}$

An important feature of individual saving behavior is the early planning for one's old-age and retirement needs, termed life-cycle saving. When individuals save for old-age needs, savings are generally higher than when saving fulfills more precautionary, short-run functions. Thus the search for when Americans began to save for the long run is a subject of great interest among those seeking the reasons why the aggregate saving rate rose across the nineteenth century. ${ }^{48}$ To use the PSFS records to observe life-cycle saving we must limit attention to the smaller sample, the linked accounts, that include the age of the account holders.

We have already established that short and long accounts, early in their histories, were similar in terms of average balance, deposits, and withdrawals. Thus, we will consider short and long accounts to be portions of the same account history. By pooling the data we can increase sample size to observe how saving changes as an individual ages, rather than just as the account ages. The graphs in Figure 1,

\footnotetext{
${ }^{47}$ Our suspicion comes from the fact that opening an account involved signing the signature record and closing an account required consulting the same large record book. Other banks at that time had separate days or hours and separate windows for the opening and closing of accounts (Olmstead, New York City Mutual Savings Banks). The clerks, it appears from the bank's history, balanced the books after hours. If one clerk handled all account openings and closings and another dealt with the more usual transactions, then a deposit or withdrawal would have occurred about every four minutes. Two clerks would have allowed twice as much time per transaction. At 20 hours a week, the bank was open 1,040 hours a year. There were 10,229 active accounts in 1850, of which 2,374 had been opened in 1850 . There was an average of 1.57 transactions-deposits and withdrawals, excluding first and last-per account per year. Given the hours of the bank and the assumption that there was one clerk for ordinary transactions, there were 15.4 transactions every hour or one every four minutes. With one clerk there could have been long queues at certain hours that discouraged transactions, although we have found no report that the bank had regular queues of customers.

${ }^{48}$ See, for example, the work of Ransom and Sutch, "Domestic Savings."
} 

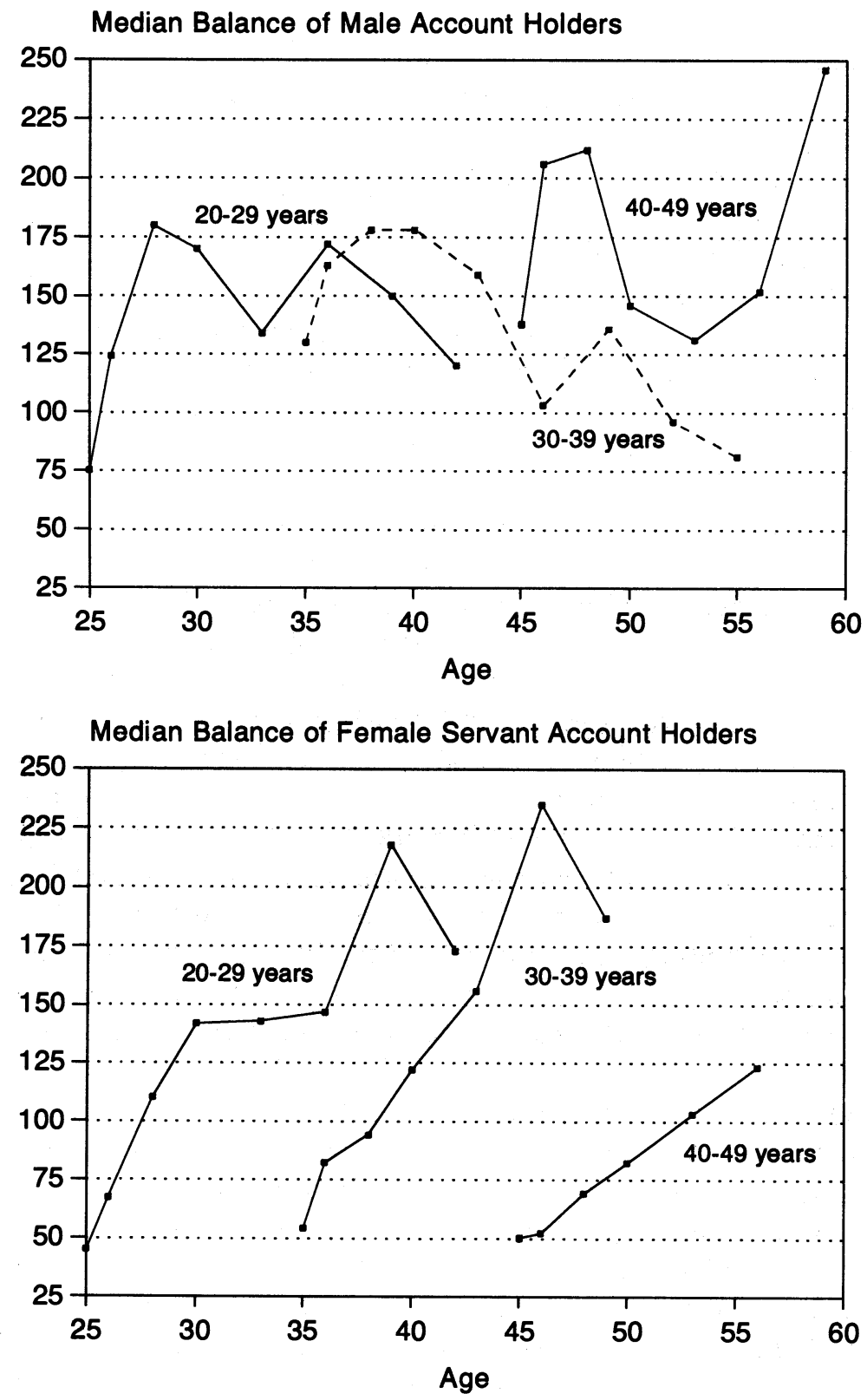

FIGURE 1

LIFE-CYCLE SAVINGS FOR MALES AND FEMALE SERVANTS, 20-49 YEARS OLD IN 1850

Notes: The intervals, 20-29, 30-39, and 40-49 are the ages of the individuals when the accounts were opened in 1850. Each data point is the median of the (deflated, $1850=100$ ) balance in all accounts (for the stated group) in a given interval $(0<1,1<2,2<4,4<6,6<9,9<12,12<$ $15,15<18,18<21$ years). Data points are not shown if the number of observations is less than four.

Source: PSFS Accounts, 1850 Linked Sample, and the notes to Table 2. 
therefore, give a life-cycle view of the account histories both in terms of the individual and the account. That is, both the age of the account holder and the age of the account are potential determinants of deposit balances. Figure 1 graphs median balance by the age of the account holder in 1850 for three age groupings. Adult males and female servants are considered separately. We exclude the female nonservants because, as noted previously, they are a very heterogeneous group and the sample sizes are too small to consider wives separately from the others.

As already discussed, the saving behavior of female servants differed from that of men. The accounts of female servants began with far less (about \$30), they added to them somewhat less often, and they withdrew from them less frequently. But what really distinguishes the accounts of female servants from those of the other two groups was that they lasted considerably longer, suggesting that they used their PSFS accounts for life-cycle saving. Of our three groups, only female servants show much evidence of continuous accumulation and thus what might be interpreted as life-cycle accumulation. The reasons may be obvious, for these women probably had few other forms of wealth, such as physical property. Because they were generally unmarried and often separated from their families of origin, they did not have access to the insurance provided by income sharing within the family nor to intergenerational transfers for old-age security. It should be recalled that we know the account holder's occupation only in 1850 , and occupations may have changed over time. Most servants opened their accounts in their twenties, and many must have subsequently married and left service. The survivors among the account holders who began as servants may have remained in service, and thus we could be observing the life-cycle savings of individuals who had no other stores of value for their old age security.

Among adult males, the age of the account holder appears to have been more important in determining his median balance than was the length of the account. Had we more linked accounts for the group who were 50 to 59 years old in 1850 , for whom the sample is too small to graph meaningfully, we could provide additional support for this statement because their accounts were substantially larger. Although there is considerable noise in the sample, the evidence in Figure 1 supports the contention that age mattered for the balances of the adult males. A 50-year old man, for example, who opened his account at age 35 had nearly the same balance as a 50-year old who opened his account at 45 . Quite the opposite appears to have been the case among the female servants. For them, account length predominated. That is, the three lines would be very similar if graphed against length of account, rather than against age. We conclude, therefore, that males, to a far greater degree than female servants, must have been moving funds from one form to another over their life cycles. Their bank accounts were a stop 
TABLE 4 MEDIAN AGE AT LAST WITHDRAWAL FOR ACCOUNTS LASTING $\geq 13$ YEARS

\begin{tabular}{cccc}
\hline \hline \multirow{2}{*}{$\begin{array}{c}\text { Age at } \\
\text { Which Account } \\
\text { Was Opened }\end{array}$} & \multicolumn{3}{c}{ Median Age at Which Account Was Closed } \\
\cline { 2 - 4 } & Males & $\begin{array}{c}\text { Female } \\
\text { Nonservants }\end{array}$ & $\begin{array}{c}\text { Female } \\
\text { Servants }\end{array}$ \\
\hline $0-14$ & 32 & 36 & \\
$15-19$ & 60 & 65 & 55 \\
$20-24$ & 37 & 49 & 50 \\
$25-29$ & 46 & 50 & 54 \\
$30-34$ & 51 & 65 & 71 \\
$35-44$ & 63 & 64 & 60 \\
$45-54$ & 61 & 65 & 65 \\
$55-64$ & 87 & 73 & \\
$\geq 65$ & 86 & 84 & \\
\hline
\end{tabular}

Source: PSFS Accounts, Linked 1850 Sample.

along the way, often to enable the accumulation of greater wealth for the purchase of another asset. Female servants, however, appear to have used their PSFS accounts for the bulk of their life-cycle saving. Their saving, therefore, began when their accounts began.

Members of all these groups whose accounts lasted more than 12 years appear to have been saving at PSFS for life-cycle reasons. As can be seen in Table 4, such individuals ended their accounts at rather old ages. Among the female servant group, the age at account closing appears to be independent of the age at which they began their accounts. ${ }^{49}$ Males who began accounts when they were 30 to 34 years old (the median age, see Table 1) closed them when they were about 51. Female servants whose accounts lasted at least 12 years and who opened them in their late twenties closed their accounts when they were in their fifties. Males and female nonservants who used PSFS for long-term saving may, like those in the servant group, have had limited access to alternative forms of accumulation such as real property.

\section{Seasonality and the Role of Occupation}

If a dominant motive for saving was to meet short-run exigencies, we should find considerable seasonality and variability by occupation in withdrawals. Unemployment data for the late nineteenth century reveal that the vast majority of laborers and manufacturing workers across the skill spectrum were idle for two to three months out of the year. ${ }^{50}$ The seasonality of withdrawals and deposits is given in Table 5 for accounts lasting at least two years. We restrict account length in this manner because a large proportion of all accounts opened in January (for

\footnotetext{
49 It should be emphasized that the sample sizes are very small for the long-lived accounts. There are 26 observations for males, 31 for female nonservants, and 19 for female servants.

${ }^{50}$ Goldin and Margo, "Downtime."
} 
TABLE 5

SEASONALITY IN WITHDRAWALS AND DEPOSITS FOR ACCOUNTS $\geq 2$ YEARS, BY OCCUPATION FOR MALES

\begin{tabular}{lcccc}
\multicolumn{5}{c}{ (percentages) } \\
\hline \hline Month & $\begin{array}{c}\text { Professional and } \\
\text { Managerial }\end{array}$ & $\begin{array}{c}\text { Trade and } \\
\text { Skilled }\end{array}$ & $\begin{array}{c}\text { Transportation and } \\
\text { Semi-skilled }\end{array}$ & Laborers \\
\hline January & & Withdrawals & & \\
February & 9.3 & 11.9 & 8.9 & 10.6 \\
March & 6.6 & 8.5 & 7.7 & 10.6 \\
April & 5.4 & 8.3 & 11.4 & 10.6 \\
May & 10.9 & 9.7 & 8.4 & 10.6 \\
June & 9.7 & 7.9 & 9.7 & 8.5 \\
July & 10.1 & 8.1 & 9.4 & 6.9 \\
August & 6.6 & 7.7 & 6.2 & 4.8 \\
September & 8.6 & 7.1 & 7.7 & 6.3 \\
October & 7.0 & 9.3 & 6.7 & 9.5 \\
November & 8.2 & 6.9 & 8.2 & 7.9 \\
December & 9.7 & 6.7 & 7.2 & 10.1 \\
& 7.8 & 8.1 & 8.7 & {$[189]$}
\end{tabular}

Deposits

\begin{tabular}{lrrrr} 
January & 13.8 & 11.1 & 10.8 & 11.0 \\
February & 9.3 & 8.6 & 8.4 & 4.9 \\
March & 7.8 & 9.2 & 9.6 & 9.9 \\
April & 10.0 & 10.4 & 9.2 & 11.4 \\
May & 7.4 & 9.5 & 9.3 & 9.1 \\
June & 9.3 & 8.9 & 8.6 & 8.7 \\
July & 10.1 & 8.9 & 8.1 & 7.9 \\
August & 7.4 & 6.9 & 7.8 & 8.0 \\
September & 7.0 & 7.8 & 8.0 & 7.1 \\
October & 5.5 & 6.7 & 6.4 & 7.9 \\
November & 4.7 & 6.5 & 7.1 & 7.4 \\
December & 7.3 & 5.6 & 6.8 & 6.6 \\
& {$[739]^{\mathrm{a}}$} & {$[1845]$} & {$[1420]$} & {$[634]$} \\
\hline
\end{tabular}

a The number of observations is in brackets and refers to the number of withdrawals or deposits, not to individual accounts.

Note: Withdrawals exclude the final withdrawal.

Source: PSFS Accounts, 1850 Sample.

reasons that are unclear). Account histories are, therefore, altered by the month of opening for at least a year.

All four occupational groups in Table 5 display a similar pattern of deposit behavior that is less seasonal than it is a declining trend throughout the year beginning in January. Just as most accounts began in January, most deposits were made in January, and, on average, fewer occurred in each successive month. One possibility is that workers were given end-of-year bonuses or Christmas presents; alternatively, the new 
year may have been a time for reckoning all accounts. ${ }^{51}$ The sums collected by the first of the year may have been deposited immediately or squirreled away until a trip to the bank was made. Because trips appear to have been made infrequently, the yearly deposit trend could result from a simple increase in cash around New Year's.

The behavior of withdrawals displays a different type of seasonality from that of deposits for one of the groups. Laborers withdrew most often from December to April, whereas all other groups have fairly flat withdrawal behavior across the year. The evidence on seasonality therefore suggests that those at the bottom end of the income spectrum used their PSFS accounts to smooth consumption over the winter months when unemployment and sickness were more common and expenses higher.

\section{Inferring Saving Rates from Account Data}

The PSFS account information can be used to make inferences about the saving rates of ordinary Philadelphians in the mid-nineteenth century. Saving appears in the PSFS data as net additions to the accounts, and annual saving divided by annual income yields the saving rate. Recall that we do not have a cross section of all accounts open in 1850 but rather all accounts that were opened in 1850 . A representative cross section of savers for a calendar year would include accounts opened in a range of earlier years. We can approximate a cross section, however, by considering the life histories of accounts opened in $\mathbf{1 8 5 0}$. Mean annual saving over the lives of these accounts approximates the mean annual saving in a cross section of accounts in an hypothetical "steady state." The steady state would result if the propensities to open and close accounts remained constant for a long time. In the steady state, the distribution of accounts by age (time since the account was opened) equals the distribution of durations of accounts followed over time. Thus, even though our estimates describe a pattern of saving unfolding over time, this process is likely to be similar to what we would observe in a cross section of accounts of different ages. ${ }^{52}$

Estimates of saving in the PSFS data are affected by the treatment of the opening and closing of accounts. One cannot know with certainty whether those who closed accounts were savers who withdrew their money in times of distress or individuals who transferred their accumu-

\footnotetext{
${ }^{51}$ Account closings did not occur with greatest frequency in January. Rather, the month of the most account closings was May, which may mean that accounts closed because people left the city. Note as well that seasonality in account opening and closing could not be related to the payment of interest, because PSFS, in contrast to the New York City banks in Olmstead's sample (Olmstead, New York City Mutual Savings Banks) paid interest on amounts held to the time of withdrawal.

52 Since most accounts were relatively brief affairs, most of the activity in these data occurred in the several years following 1850 . We have also excluded information after 1880, because a few atypical accounts appear to have undue influence on our sample in later years.
} 
lated funds to property or other financial assets. It seems clear from the size of the accounts when they closed that the majority were not ended by the "precautionary" saver group. Rather, at least among male account holders, they were individuals whose goals appear to have been met. The subsample linked to the city and business directories suggests that physical property was purchased with the fruits of their thrift. Because the opening and closing of PSFS accounts often involved the movement of funds from one type of asset to another, we exclude the first deposit and last withdrawal from our estimates.

Accounts often became inactive over time, and many that survived the first five years have subsequent deposit activity only once every three years rather than once or twice a year. Such inactivity could indicate that the person ceased saving entirely or was saving in another form. We can accommodate either interpretation by constructing mean savings rates for two groups-all open accounts and active accounts.

The mean change in account balances for all adult males with open accounts was $\$ 57$ in the first year (1851), \$35 in the second, and $\$ 44$ in the third. The mean change declined substantially after the first three to four years, however. Among males who opened an account in 1850, mean annual saving over the entire length of the account was about $\$ 27$. Among female servants, it was about $\$ 18$.

Many accounts were severely drained during the Civil War years, and including this unique period could produce misleading estimates. Even when we exclude the Civil War years, the 1850 accounts cover several periods of economic recession, such as 1857 . The means without the Civil War decade are $\$ 31$ for males and $\$ 17$ for female servants. That for male laborers was $\$ 34$, and that for male artisans was $\$ 37$.

Another estimate of saving focuses on the active accounts only. Here we assume that inactive accounts do not represent inactivity of individual savings but rather inactivity in a particular form (that is, in a savings bank). We define inactivity as no transactions, either deposits or withdrawals, in a given year. For adult males, annual saving (again, in the absence of the Civil War decade) increases to $\$ 42$, and that for female servants to $\$ 23$, when only years with some activity are used. That for male laborers was $\$ 47$, and that for male artisans was $\$ 46$.

We have, then, several estimates of annual saving and, when divided by an annual income figure, several estimates of the saving rate. Our best estimate for the annual income of male laborers in 1850 is $\$ 280$ (see note 40). The PSFS accounts of male laborers imply a saving rate of 12 percent (17 percent when only active accounts are included) ${ }^{53}$ The rates would be somewhat lower for artisans ( 10 percent and 12 percent), given our best estimate of their annual incomes. ${ }^{54}$

53 These estimates exclude the Civil War decade.

${ }^{54}$ This assumes an annual income of $\$ 373$, or, consistent with note $40, \$ 1.434 /$ day $\times 26$ days per 
The earliest comparable data that we have found is for Michigan furniture workers in $1889 .{ }^{55}$ For each family we have the amount earning interest in a savings bank or elsewhere, the amount of saving, and the earnings of the worker. ${ }^{56}$ Thus we can select cases with attributes similar to those in the PSFS sample, most notably that the individual had a savings account (or had money earning interest). Among the Michigan furniture workers, men with money earning interest had (median) annual savings of $\$ 60$ and mean income of $\$ 540$, yielding a saving rate of 11 percent. ${ }^{57}$

Although comparability between the two sets of data is not perfect, it does appear that those saving at PSFS saved a substantial fraction of their income. ${ }^{58}$ The saving rates computed for active accounts (at least one withdrawal or deposit per year), appear to be quite high, particularly for laborers and domestics. When their accounts were active, PSFS account holders were probably putting all of their savings into their accounts. Thus, even though we have analyzed only one financial instrument, it is likely that all savings were channeled in this direction when the accounts were active.

\section{SUMMARY}

We have analyzed the full history of all saving accounts opened in 1850 at the Philadelphia Saving Fund Society, the first mutual savings bank in the United States. Although the account holders at PSFS were a diverse lot, accounts opened in 1850 can be characterized as relatively large in size, brief in duration, and inactive. Most savers were not, it appears, using PSFS to tide them over from month to month to meet the exigencies we know they faced. The amounts that were withdrawn were large in comparison with income, and the amounts that were deposited were also fairly large. The PSFS accounts do not seem to have been used to fulfill precautionary motives as we had imagined they would. That said, one group of savers-adult male laborers-did withdraw far more frequently in the winter, but withdrawals were still infrequent

month $\times 10$ months. Note that the saving rate for servants would be considerably higher if we considered only their discretionary income and not that given in-kind.

${ }^{55}$ See Goldin and Margo, "Downtime," for a discussion of this data set. Adams, "Earnings," analyzed the savings of workers at the DuPont gunpowder mill from 1813 to 1860 and found saving rates of about 15 percent. Saving among these workers was made particularly costless and may even have been encouraged by the firm's manner of crediting their wages directly to their accounts. DuPont workers were, moreover, not a representative cross section of ordinary Americans.

${ }^{56}$ It should be noted that we use the stated amount of savings, not the amount derived from family earnings minus family expenditures. The latter estimate is considerably higher than that reported by the families, suggesting that stated expenditures did not exhaust the total for the year. It should also be pointed out that there were very few cases of dissaving in the sample.

57 Curiously, there are few negative values and many missing values for saving.

${ }^{58}$ Of course, we do not know the income of our savers. Higher income would decrease the saving rate and lower income would increase it. 
events. Most savers must have had access to other forms of credit, such as relying on the kindness of family and friends. For many savers, particularly adult males, PSFS provided a means to meet their targets by storing and accumulating funds for the purchase of other assets.

Although most PSFS account holders seem to have been target savers, there were discernible subgroups whose motives for having savings accounts appear to have been life cycle in origin. Many female servants, at least at the end of their account histories, had saved for old-age security. Without access to family and not having property, female servants were a likely group to have saved in this fashion. We also see evidence that those who lived as boarders used their accounts to save for the long term.

What do these accounts tell us about the amounts working-class people saved in the mid-nineteenth century and about the role of savings banks like PSFS? We cannot be certain that our savers did not have accounts elsewhere, although their options were extremely limited in 1850 , and we know that some owned real property or lived with others who did. Thus, the savings accounts give us a lower bound to the net worth of our account holders, albeit a good estimate of liquid wealth other than currency or specie. On the other hand, we are capturing individuals who opened savings accounts and thus had accumulated a sufficient amount of cash (and acquired ample mental fortitude) to engage in institutional thrift. With these caveats in mind, the account histories suggest relatively large amounts of savings. Among male account holders whose accounts lasted four to five years, the median balance was almost equal to annual gross income, and the annual saving rate for active accounts was around 10 to 15 percent.

We can compare that fraction with a similarly constructed number for the more recent period. In 1983 median family income in America was about $\$ 20,000$. Median liquid assets (for example, checking, saving, money market, certificates of deposit) for families in that range who held any assets of this type were about $\$ 1,800$ (although the mean was about $\$ 10,000$ ) or 10 percent of median family income. Median total financial assets (including liquid assets plus, for example, bonds and stocks) of families in that range, and again for families with some assets of that type, were about $\$ 2,000$ (although $\$ 13,000$ for the mean). ${ }^{59}$ Thus, by just about any standards, those who saved at PSFS had, as a fraction of their annual gross income, accumulated a large nest egg.

We began with a statement about the rise of aggregate savings in the nineteenth century and the need to discover how it was that Americans

\footnotetext{
59 Thus we are conditioning in precisely the same manner as the PSFS accounts implicitly are, namely the mean level of savings conditional on having any savings, defined in some manner. 1983 figures are drawn from United States Board of Governors of the Federal Reserve, "Survey, 1983," p. 686.
} 
managed to amass such ample savings at that time. By using savings accounts, such as those at PSFS, some Americans who did not have the security of family saved for life-cycle reasons. Many used these accounts to accumulate funds to purchase another asset, possibly also to fulfill a life-cycle function. Did PSFS, through its role in decreasing transactions costs and paying interest; increase the supply of funds? Or did the bank merely enable the more efficient allocation of capital by intermediating between savers and borrowers? We have no obvious proof, but it seems to us that "the large classes of humble and helpless, but thrifty and prudent" would have found it far more difficult to accumulate in the absence of PSFS, although they may have met their month-to-month exigencies in exactly the same manner.

\section{REFERENCES}

Adams, Donald R., "Earnings and Savings in the Early Nineteenth Century," Explorations in Economic History, 17 (Apr. 1980), pp. 118-34.

Davis, Lance, and Robert Gallman, "Capital Formation in the United States during the Nineteenth Century," in The Cambridge Economic History of Europe, vol. 7, The Industrial Economies: Capital, Labour, and Enterprise, part 2 (Cambridge, 1978), pp. $1-69$.

Deaton, Angus, "Saving and Liquidity Constraints," National Bureau of Economic Research Working Paper No. 3196 (Dec. 1989).

Fishlow, Albert, "The Trustee Savings Banks, 1817-1861," this Journal, 21 (Mar. 1961), pp. $26-40$.

Goldin, Claudia, and Robert A. Margo, "Downtime: Voluntary and Involuntary Unemployment" (Unpublished manuscript, 1991).

Goldin, Claudia, and Robert A. Margo, "Wages, Prices, and Labor Markets before the Civil War," in C. Goldin and H. Rockoff, eds., Strategic Factors in Nineteenth Century American Economic History (Chicago, 1992), pp. 67-104.

Hershberg, Theodore, et al., "Occupation and Ethnicity in Five Nineteenth Century Cities: A Collaborative Inquiry," Historical Methods Newsletter, 7 (June 1974), pp. 174-216.

Hershberg, Theodore, and Henry Williams, "Mulattoes and Blacks: Intra-group Color Differences and Social Stratification in Nineteenth Century Philadelphia," in T. Hershberg, ed., Philadelphia: Work, Space, Family, and Group Experience in the Nineteenth Century (New York, 1981), pp. 392-434.

Johnson, Paul, Saving and Spending: The Working-class Economy in Britain, 1870-1939 (Oxford, 1985).

King, Mervyn, "The Economics of Saving: A Survey of Recent Contributions," in K. J. Arrow and S. Honkapohja, eds., Frontiers of Economics (New York, 1985), pp. 227-294.

Lebergott, Stanley, Manpower in Economic Growth: The American Record since 1900 (New York, 1964).

Olmstead, Alan L., New York City Mutual Savings Banks, 1819-1861 (Chapel Hill, 1976).

Payne, Peter Lester, and Lance Edwin Davis, The Savings Bank of Baltimore, 1818-1866: A Historical and Analytical Study (Baltimore, 1956). 
Philadelphia Saving Fund Society, Accounts, Hagley Museum and Library, Wilmington, DE, accession no. 2060.

Philadelphia Saving Fund Society, Annual Report for the Year 1850 (Unpublished handwritten document, Philadelphia, Jan. 6, 1851, Hagley Museum and Library, Wilmington, DE).

Ransom, Roger L., and Richard Sutch, "Domestic Saving as an Active Constraint on Capital Formation in the American Economy, 1839-1928: A Provisional Theory," Working Papers on the History of Saving, No. 1 (Dec. 1984).

Rotella, Elyce, From Home to Office: U.S. Women at Work, 1870-1930 (Ann Arbor, 1981).

United States Board of Governors of the Federal Reserve, "Survey of Consumer Finances, 1983," Federal Reserve Bulletin (Sept. 1984).

U.S. Bureau of the Census, Compendium of the Seventh Census of the United States: 1850 (Washington, DC, 1853).

U.S. Bureau of the Census, Seventh Census of the United States, Volume I: 1850 (Washington, DC, 1853).

U.S. Bureau of the Census, Ninth Census of the United States, Volume I, Population: 1870 (Washington, DC, 1872).

United States Bureau of the Census, Historical Statistics of the United States: From Colonial Times to the Present (Washington, DC, 1975).

Willcox, James M., A History of the Philadelphia Saving Fund Society, 1816-1916 (Philadelphia, 1916). 